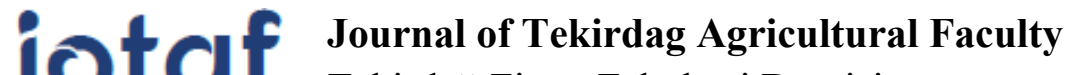

Tekirdağ Ziraat Fakültesi Dergisi

Ocak/January 2022, 19(1)

Başvuru/Received: 27/08/21

Kabul/Accepted: 05/11/21

DOI: $10.33462 /$ jotaf.987700

http://dergipark.gov.tr/jotaf

http://jotaf.nku.edu.tr/

ARAŞTIRMA MAKALESI

RESEARCH ARTICLE

\section{Farklı Yöntemlerle Anadolu Manda Tereyağı Üretimi}

Production of Anatolian Water Buffalo Butter Using Different Methods

İbrahim Halil ESER ${ }^{1}$, Ahmet Levent İNANÇ ${ }^{2^{*}}$

\section{$\ddot{O} \mathbf{z}$}

Bu çalışmada Anadolu manda sütünden üç farklı yöntemle (tatlı krema, ekşi krema ve yoğurttan) manda tereyağı üretilmiştir. Uygulanan üretim yöntemleri karşılaştırılarak tereyağların bazı kimyasal özellikleri incelenmiştir. Hammadde olarak kullanılan manda sütünün yağ içeriğinin \% 7, toplam kuru madde (yağ dahil) oranının \%16.20 ve randımanının \% 7-8.5 aralığında olduğu tespit edilmiştir. Bütün tereyağlarda ortalama \%83.64 yağ içerdiği belirlenmiştir. Tereyağların $\mathrm{pH}$ değerlerinde önemli farklılık bulunmamıştır ( $\mathrm{p}>0.05)$. En yüksek titrasyon asitliği $(\% 0.43)$ ve en düşük serbest yağ asitliği (\%0.80) yayık tereyağında (yoğurttan yapılmış) tespit edilmiştir. Sütün peroksit değeri 0.1 meq $\mathrm{O}_{2} \mathrm{~kg}^{-1}$, tereyağların 1.94-2.01 meq $\mathrm{O}_{2} \mathrm{~kg}^{-1}$ olarak bulunmuştur. Sütteki vitamin miktarları tereyağlara göre düşük olduğu tespit edilmiştir $(\mathrm{p}<0.05)$. Tereyağların vitamin $\mathrm{A}, \mathrm{D}, \mathrm{E}, \mathrm{K}_{1}$ ve $\mathrm{K}_{2}$ değerleri sırasıyla 20.60-22.40 $\mu \mathrm{g} \mathrm{g}^{-1}, 3.56-4.20 \mathrm{ng} \mathrm{g}^{-1}, 24.40-33.20 \mathrm{ng} \mathrm{g}^{-1}, 59.20-72.80 \mathrm{ng} \mathrm{g}^{-1}$ ve 64.20-123.00 $\mathrm{ng} \mathrm{g}^{-1}$ olarak belirlenmiştir. Sütün kolesterol miktarı $69 \mu \mathrm{g} \mathrm{g}{ }^{-1}$ olarak bulunurken tereyağların kolesterol miktarları 1490-2953 $\mu \mathrm{g} \mathrm{g}^{-1}$ aralığında bulunmuştur. En yüksek kolesterol içeriği yayık tereyağında bulunmuştur. Tereyağların ve sütün yüzde yağ asit kompozisyonları arasında fark bulunmamıştır ( $\mathrm{p}>0.05)$. Ortalama $\%$ yağ asit değerleri; bütirik asit $\left(\mathrm{C}_{4: 0}\right) 3.799 \pm 0.060$, kaproik asit $\left(\mathrm{C}_{6: 0}\right) 1.253 \pm 0.020$, kaprilik asit $\left(\mathrm{C}_{8: 0}\right)$ 0.729 \pm 0.017 , kaprik asit $\left(\mathrm{C}_{10: 0}\right) \quad 1.359 \pm 0.035$,

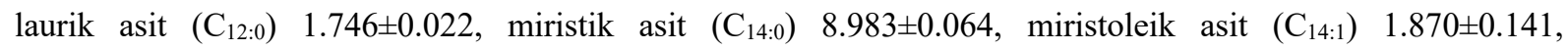
pentadekanoik asit $\left(\mathrm{C}_{15: 0}\right)$ 1.965 \pm 0.032 , cis-10-pentadekanoik asit $\left(\mathrm{C}_{15: 1}\right)$ 0.863 \pm 0.028 , palmitik asit $\left(\mathrm{C}_{16: 0}\right)$ 36.066 \pm 0.498 , palmiteloik asit $\left(\mathrm{C}_{16: 1}\right) 3.261 \pm 0.026$, heptadekanoik asit $\left(\mathrm{C}_{17: 0}\right)$ 1.176 \pm 0.034 , cis-10-heptadekanoik asit $\left(\mathrm{C}_{17: 1}\right)$ 0.466 \pm 0.007 , stearik asit $\left(\mathrm{C}_{18: 0}\right) 9.300 \pm 0.075$, oleik asit $\left(\mathrm{C}_{18: 1}\right) 24.194 \pm 0.429$, linoleik asit $\left(\mathrm{C}_{18: 2}\right)$ $1.061 \pm 0.071, \alpha$-linolenik asit $\left(\mathrm{C}_{18: 3}\right) 0.342 \pm 0.024$, araşidik asit $\left(\mathrm{C}_{18: 0}\right)$ 0.184 \pm 0.017 , cis-11-eikosenoik asit $\left(\mathrm{C}_{20: 4}\right)$ $0.602 \pm 0.060$, heneikosanik asit $\left(\mathrm{C}_{21: 0}\right) \quad 0.130 \pm 0.001$, behenik asit $\left(\mathrm{C}_{22: 0}\right) \quad 0.252 \pm 0.013$, erusik asit $\left(\mathrm{C}_{22: 1}\right)$ $0.163 \pm 0.020$, trikosenoik asit $\left(\mathrm{C}_{23: 1}\right) 0.181 \pm 0.006$, lignoserik asit $\left(\mathrm{C}_{24: 0}\right) 0.147 \pm 0.004$ olarak saptanmıştır.

Anahtar Kelimeler: Kolesterol, Manda sütü, Tereyağ, Vitamin, Yağ asit kompozisyonu

\footnotetext{
${ }^{1}$ İbrahim Halil ESER, Kahramanmaraş Sütçü İmam Üniversitesi, Mühendislik-Mimarlık Fakültesi, Gıda Mühendisliği Bölümü, 46060, Kahramanmaraş, Türkiye. E-mail: ibrhmhall@hotmail.com (iD) OrcID: 0000-0002-9550-9306

$2^{2 *}$ Sorumlu Yazar/Corresponding Author: Ahmet Levent INANÇ, Kahramanmaraş Sütçü İmam Üniversitesi, Mühendislik-Mimarlık Fakültesi, Gıda Mühendisliği Bölümü, 46060, Kahramanmaraş, Türkiye E-mail: linanc@ksu.edu.tr (D) OrcID: 0000-0002-7363-5096. Atıf/Citation: ESER, İ.H, İNANÇ, A.L. Farklı Yöntemlerle Anadolu Manda Tereyağı Üretimi. Tekirdă̆ Ziraat Fakültesi Dergisi, 19 (1), $215-226$.

*Bu çalışma Yüksek Lisans tezinden özetlenmiştir.

CBu çalışma Tekirdağ Namık Kemal Üniversitesi tarafından Creative Commons Lisansı (https://creativecommons.org/licenses/by-nc/4.0/) kapsamında yayınlanmıştır. Tekirdağ 2022 


\begin{abstract}
In this study, buffalo butter was produced from Anatolian buffalo milk by three different methods (sweet cream, sour cream and yogurt). Some chemical properties of butters were investigated by comparing the applied production methods. It has been determined that the fat content of buffalo milk used as raw material is $7 \%$, the total dry matter ratio is $16.20 \%$, and its yields vary between $7-8.5 \%$. All of the butters contained an average of $83.64 \%$ fat $(\mathrm{p}>0.05)$. No significant difference was found in the $\mathrm{pH}$ values of the butters $(\mathrm{p}>0.05)$. The highest titration acidity $(0.43 \%)$ and the lowest free fatty acidity $(0.80 \%)$ were determined in yayı butter (made from yogurt). Peroxide value of milk was $0.1 \mathrm{meq} \mathrm{O}_{2} \mathrm{~kg}^{-1}$, and 1.94-2.01 meq $\mathrm{O}_{2} \mathrm{~kg}^{-1}$ for the butter samples. The amounts of the vitamins in the milk were found to be lower than in the butters $(\mathrm{p}<0.05)$. The vitamin $(\mathrm{A}, \mathrm{D}, \mathrm{E}, \mathrm{K} 1$ and K2) values of the butters were 20.60-22.40 $\mu \mathrm{g} \mathrm{g}^{-1}, 3.56-4.20 \mathrm{ng} \mathrm{g}^{-1}, 24.40-33.20 \mathrm{ng} \mathrm{g}^{-1}, 59.20-72.80 \mathrm{ng} \mathrm{g}^{-1}$ and 64.20-123.00 $\mathrm{ng} \mathrm{g}^{-1}$, respectively. The amount of cholesterol in milk was found to be $69 \mu \mathrm{g} \mathrm{g}^{-1} \mathrm{while}$ that of butter was found to be in the range of $1490-2953 \mu \mathrm{g} \mathrm{g}^{-1}$. The highest cholesterol content was found in yay1k butter. There was no difference between fatty acid compositions of the butters and the milk $(\mathrm{p}>0.05)$. The percentages of average fatty acid values were evaluated as follows; butyric acid $\left(\mathrm{C}_{4: 0}\right) 3.799 \pm 0.060$, caproic acid $\left(\mathrm{C}_{6: 0}\right)$ 1.253 \pm 0.020 , caprylic acid $\left(\mathrm{C}_{8: 0}\right) \quad 0.729 \pm 0.017$, capric acid $\left(\mathrm{C}_{10: 0}\right) \quad 1.359 \pm 0.035$, lauric acid $\left(\mathrm{C}_{12: 0}\right)$ 1.746 \pm 0.022 , miristic acid

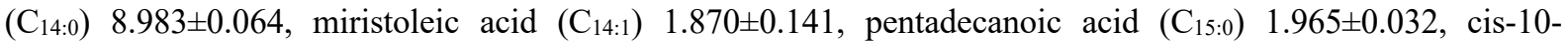
pentadecanoic acid $\left(\mathrm{C}_{15: 1}\right)$ 0.863 \pm 0.028 , palmitic acid $\left(\mathrm{C}_{16: 0}\right)$ 36.066 \pm 0.498 , palmiteloic acid $\left(\mathrm{C}_{16: 1}\right)$ 3.261 \pm 0.026 , heptadecanoic acid $\left(\mathrm{C}_{17: 0}\right)$ 1.176 \pm 0.034 , cis-10-heptadecanoic acid $\left(\mathrm{C}_{17: 1}\right)$ 0.466 \pm 0.007 , stearic acid $\left(\mathrm{C}_{18: 0}\right)$

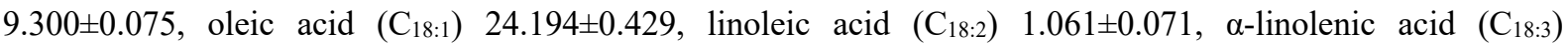
$0.342 \pm 0.024$, arasidic acid $\left(\mathrm{C}_{18: 0}\right) \quad 0.184 \pm 0.017$, cis-11-eicosenoic acid $\left(\mathrm{C}_{20: 4}\right)$ 0.602 \pm 0.060 , heneicosanic acid $\left(C_{21: 0}\right)$ 0.130 \pm 0.001 , behenic acid $\left(C_{22: 0}\right) 0.252 \pm 0.013$, erucic acid $\left(C_{22: 1}\right) 0.163 \pm 0.020$, tricosenoic acid $\left(C_{23: 1}\right)$ $0.181 \pm 0.006$, lignoceric acid $\left(\mathrm{C}_{24: 0}\right) 0.147 \pm 0.004$.
\end{abstract}

Keywords: Buffalo milk, Butter, Cholesterol, Fatty acid composition, Vitamin 


\section{Giriş}

İnsan beslenmesinde büyük öneme sahip olup vücutta sentezlenemeyen esansiyel aminoasitleri içinde bulunduran bir gıda maddesi olan süt, beslenme yetersizliği ile karşı karşıya olduğumuz şu dönemde büyük bir öneme sahip olup, direkt süt olarak ya da değişik lezzet, aroma, şekil ve yapıda birçok ürüne dönüştürülüp süt ürünleri şeklinde tüketilmektedir.

Birleşmiş Milletler Gıda ve Tarım Örgütü (FAO)'nün en son 2019 yılı verilerine göre Dünya'daki Manda baş sayıs1 204.342.419'dir. Manda varlığının \%97.1'ni oluşturan 198.414.255 baş manda Asya'da, geri kalan kısmın \%1.7'i (3.476.421) Afrika'da, \%1'i (1.985.388) Amerika ve \%0.2'i (466.175) Avrupa'da bulunmaktadır. Türkiye'de ise 2021 yılı Türkiye İstatistik Kurumu (TÜIK) verilerine göre 194.277 baş manda bulunmaktadır. Sağılan baş mandalardan, 79.341 ton/yıl süt elde edilmektedir (FAO, 2021a; TÜIK. 2021a). Dünyada 2008 yılında 1.344.244 ton olan tereyağı üretimi varken, en son verinin alındığı 2018 yılına geldiğinde 10 yılda yaklaşık \%27'lik artış göstererek 11.344.244 tona ulaşmıştır. Dünya tereyağı üretiminin \%2.22'si Türkiye'de gerçekleştirilmektedir (FAO, 2021b). Ancak, Türkiye'de Ocak-Haziran/2021-2020 döneminde bir önceki y1lın aynı dönemine göre tereyağı üretiminde \%4.1 azalma görülmektedir (TÜIK, 2021b).

Manda sütü, başta tereyağı, lüle kaymağı ve yoğurt olmak üzere Afyon Kaymağı, Mozzarella peyniri, dondurma ve içme sütü olarak kullanılmaktadır. İçme sütü olarak manda sütü fazla tüketilmemektedir. İçme sütü olarak tüketilen manda sütü miktarı toplam üretimin sadece $\% 0.1$ 'idir. Manda sütünün kuru maddesinin yüksek olduğu için sütün işlendiği ürünlerin randımanı da yüksektir. Yağ oranı yüksek olmasına rağmen kolesterol değeri inek sütüne göre daha düşüktür. Kolesterol değerinin düşük olması, yağ globüllerinin çapının küçük olmasına bağlı olarak çoklu doymamış yağ asitlerince zengin olmasından kaynaklanmaktadır (Zicarelli, 2004). İnek sütüyle kıyaslandığında özel diyetlerde kullanımı daha sağlıklıdır. Manda sütünü üstün kılan diğer bir özelliği ise rengidir. Manda sütünün bileşiminde bulunan karoten, A vitamini olarak bulunduğundan manda sütü ve ürünlerinin rengi inek sütüne göre daha beyazdır (Metin, 2008; Üçüncü, 2005). Mandaların süt verimleri yetiştirildikleri işletmelerin ekonomisinde önemli yer tutar. Bu veriler ışığında manda sütü ve ürünleri, üretici ve tüketicilere oldukça önemli bir seçenek sunmaktadır (Demiryürek, 2004).

Tereyağı, sütün en önemli bileşeni olan süt yağından oluşur. Süt yağı doğadaki en karmaşık yağlardan biridir. Bu karmaşıklık içeriğinde bulunan yağ asitlerinin çeşitliliğinden (zincir uzunluğu -kısa, orta, uzun-, doymamışlık derecesi ve dallanma gibi) kaynaklanmaktadır (Metin, 2008; Fatouh ve ark., 2005). Tereyağı ya direkt olarak tüketilmekte ya da firın ürünleri gibi işlem görmüş pek çok ticari üründe katkı maddesi olarak kullanılmaktadır. Yüksek oranda süt yağı, esansiyel yağ asitleri ve vitamin içeriği ile besleyici özelliğe sahip olan tereyağı, tüketiciler tarafından en fazla tercih edilen yağlardan birisidir. Dünyada üretilen tereyağları ağırlıklı olarak inek, manda ve koyun sütünden yapılmaktadır. En az \%82 süt yağı içeriğine sahip olan tereyağı; süt, krema ya da yoğurdun değişik şekillerde işlenmesiyle elde edilen tereyağının modern işletmelerdeki yapımında genel olarak krema hammadde olarak kullanılmaktadır. Türkiye'de yoğurttan üretilmiş tereyağı, kremadan elde edilene göre daha fazla tercih edilmektedir. Ancak üretiminin zahmetli olması ve otomasyona uygun olmayışı nedeniyle üretimi ekonomik olmayıp, endüstriyel olarak üretilmemektedir. Günümüzde, geleneksel olarak küçük çapta bazı aile işletmelerinin kendi ihtiyaçları için ürettiği, ticari olarak zor bulunan bir tereyağı olduğu da bir gerçektir. Dünyada genel olarak, ekşi kremadan (starter kültür ilave edilerek), tatlı kremadan (ekşitilmeden) ve laktik asit + aroma konsantresi ile asitlendirilmiş tatlı kremadan olmak üzere üç farklı tip üretim tekniği vardır (Mallia ve ark., 2008a).

Bu çalışmada, manda sütü kullanılarak üç farkı yöntemle yayık ve krema tereyağları üretilmiştir. Üretilen tereyağların bazı kimyasal özellikleri karşılaştırılmıştır.

\section{Materyal ve Metot}

Çiğ manda sütü Kahramanmaraş ili Andırın ilçesinden temin edilmiştir. Yoğurt kültürü (CH-1, 50U) ve mezofilik aromatik tereyağ kültürü (F-DVS CHN-22) Chr Hansen Gıda Sanayi ve Ticaret Anonim Şirketinden (İstanbul) satın alınmıştır.

\subsection{Sütün sterilizasyonu}

Çiğ sütün sterilizasyonu otoklavda (Selecta, Presoclave 75 modeli) $121^{\circ} \mathrm{C}$ 'de $3 \mathrm{dk}$. 1sıl işlem uygulaması ile gerçekleştirilmiş̧ir (TGK, 2000). 


\subsection{Yoğurt yapımı}

Süte yoğurt kültürü ilave edilerek $44^{\circ} \mathrm{C}$ 'de 4 saat inkübasyona tabi tutulmuştur. Daha sonra (yaklaşık pH 4.6) $4^{\circ} \mathrm{C}$ 'de 24 saat olgunlaştırma işlemi için depolanmıştır.

\subsection{Yayık tereyağı üretimi}

Yoğurt; 1:2 oranında soğuk su eklenerek, oda sıcaklığında küçük ev tipi yayık makinesinde (Minisan Kaymakçı 5 Litre Yayık Makinesi) yayıklanmıştır. Yayıklama işlemi yaklaşık $35 \mathrm{dk}$. sonra sonlandırılmıştır. Yayıklama sonrasında oluşan tereyağ granülleri toplanmış yayıkaltı ayranından ayrılmıştır. Yoğurttan üretilen bu tereyağı "yayık tereyağı” olarak adlandırılmıştır. Tereyağı içerisinde bulunan yayıkaltı ayranından tamamen ayırılması için su ile yıkama işlemi (3 defa) yapılmıştır. Tereyağa uniform yapı kazandırmak için içerisindeki su baskı uygulanarak uzaklaştırılmıştır. Elde edilen tereyağı derin dondurucuda saklanmıştır.

\subsection{Tatlı krema tereyă̆ı üretimi}

Asya Zenit Süt Krema makinasıyla kremanın sütten ayrılması sağlanmıştır. kremaya 1:1 oranında soğuk su eklenerek oda sıcaklığında $35 \mathrm{dk}$. yayıklama işlemi gerçekleşmiştir. Yayıklama sonrasında oluşan tereyağ granülleri toplanmıştır. Su ile 3 defa yıkama işlemi gerçekleştirilmiştir. Tereyağa uniform yapı kazandırmak için içerisindeki su baskı uygulanarak uzaklaştırılmıştır. Elde edilen tereyağı derin dondurucuda saklanmıştır.

\subsection{Ekşi krema tereyağı üretimi}

Tatlı krema tereyağı üretimindeki gibi krema sütten ayrıştırılmıştır. Kremaya mezofilik starter kültürü ilave edilerek $20-25^{\circ} \mathrm{C}$ 'de $\mathrm{pH}$ 5.0-5.2 oluncaya kadar olgunlaştırma işlemi gerçekleştirilmiştir. Olgunlaşma işleminin ardından $10^{\circ} \mathrm{C}$ 'ye soğutulan krema yayık makinasına alınıp, krema miktarı kadar soğuk su eklenerek oda sıcaklığında yayıklanmıştır. Yayıklama $35 \mathrm{dk}$. sonra sonlandırılmıştır. Yayıklama sonrasında oluşan tereyağı granülleri toplanmış yayıkaltı ayranından ayrılmıştır. Tereyağ $3 \mathrm{kez}$ su ile yıkanmıştır. Sonra uniform yapı kazandırmak amacıyla içerisindeki su baskı uygulanarak uzaklaştırılmıştır. Elde edilen tereyağı derin dondurucuda saklanmıştır.

\subsection{Analizler}

\subsubsection{Su miktart}

Tereyağı örneklerinin su içeriği TS 1331/T1 Tereyağı Standardına göre belirlenmiştir (TSE, 2015). Tereyağı örnekleri $(5 \mathrm{~g}), 102 \pm 2^{\circ} \mathrm{C}^{\prime}$ ye ayarlanmış etüvde sabit ağırlığa gelinceye kadar bekletilmiştir.

\subsubsection{Yăg miktarı}

Yağ tayini uygun bütirometreler kullanılarak AOCS (2000b)'de belirtilen 2000.18 metoduna göre yapılmıştır. $5 \mathrm{~g}$ tereyağı örneği tartılıp bütirometre tüpüne konulduktan sonra tüp bütirometreye yerleştirilmiş̧tir. Bütirometrenin üst boşluğundan 1.820 özgül ağırlığında $10 \mathrm{~mL}$ sülfürik asit ve $1 \mathrm{~mL}$ amil alkol konulduktan sonra, yakma işlemi gerçekleştirilmiş ve 10 dakika santrifüj işlemi uygulanmıştır. İşlem sonunda bütirometrlerin taksimatlı kısmından tereyağının yağ miktarı yüzde olarak okunmuştur.

\subsubsection{Randıman}

Randıman, elde edilen ürün miktarının hammadde miktarına oranıdır. Süt ve tereyağların miktarları esas alınarak hesaplanmıştır.

\subsection{4. $\mathrm{pH}$}

$40^{\circ} \mathrm{C}$ 'yi geçmeyen su banyosunda tereyağı eritilerek Mettler Toledo marka digital pH metre ile ölçüm yapılmıştır.

\subsubsection{Titrasyon asitliğ $i$}

Yağ örneklerinin titrasyon asitlik değerinin belirlenmesi için bir behere yaklaşık $5 \mathrm{~g}$ örnek tartılmıştır. $50 \mathrm{~mL}$ alkol ve eter (1:1) çözeltisi karıştırıldıktan sonra 2 damla \%1'lik fenolfitalein ilave edilerek $0.1 \mathrm{~N} \mathrm{NaOH}$ çözeltisi ile titre edilmiştir. Yağın titrasyon asitliği \% laktik asit cinsinden hesaplanmıştır (TSE, 1995). 


\subsubsection{Peroksit sayısı}

Şilifli bir erlene $5 \mathrm{~g}$ tereyağı örneği tartılmış ve çözünmesi için $10 \mathrm{~mL}$ kloroform ilave edildikten sonra hızlı bir şekilde karıştırılmış, üzerine $15 \mathrm{~mL}$ asetik asit ve $1 \mathrm{~mL}$ doymuş potasyum iyodür ilave edilmiş ve kapağı kapatılmıştır. Daha sonra $1 \mathrm{dk}$. karıştııılıp $5 \mathrm{dk}$. karanlık ortamda bekletilmiştir. $75 \mathrm{~mL}$ kaynatılmış ve oda sıcaklığına soğutulmuş sudan ilave edilip kuvvetlice çalkalandıktan sonra $1 \mathrm{~mL}$ nişasta çözeltisi eşliğinde $0.01 \mathrm{~N}$ sodyum tiyosülfat çözeltisi ile titre edilmiştir. Sonuçlar meq $\mathrm{O}_{2} \mathrm{~kg}^{-1}$ cinsinden verilmiştir (AOCS, 2006).

\subsubsection{Serbest yă̆ asitliğ}

Süt yağını ayırmak için numune $50-60^{\circ} \mathrm{C}$ de eritilerek 2-3 saat kendi halinde bırakılmıştır. Berrak kısım alınarak kuru bir süzgeç kağıdından süzülmüştür. Hazırlanan deney numunesinden 5-10 g (0.01g hassasiyette) tartılmış, üzerine 50-100 mL nötrleştirilmiş etanol-dietil eter karışımı katılmış ve süt yağının çözülmesi sağlanmıştır. 2 damla fenol fitaleyn çözeltisi katılarak en az 10 saniye kalabilen solgun pembe bir renk oluşana kadar $0.1 \mathrm{~N}$ etanollü $\mathrm{KOH}$ çözeltisi ile titre edilmiştir. Serbest yağ asitliğinin birimi \% oleik asit cinsinden verilmiştir (AOCS, 2009).

\subsubsection{Yağda çözünen vitaminler}

Vitamin analizleri HPLC cihazı ile yapılmıştır. HPLC (Shimadzu LC-20AT); SIL 20AT HT model Otomatik örnekleyici ünitesi, DGU-20A5R model gaz arındırma ünitesi, CTO-10ASVP model kolon firını ünitesi ve LCsolution version 1.25 yazılım programına sahiptir. A, E ve K vitaminleri için floresan dedektörü (Shimadzu RF-20A), D vitamini için UV dedektörü (Shimadzu SPD 20A) kullanılmıştır. Vitamin A (retinol) 2001.13, Vitamin D3 (kolekalsiferol) 2002.05, Vitamin E (alfa tokoferol) 992.03 ve Vitamin K1 (fillokinon) ile Vitamin K2 (menakinon-4) 999.15 numaralı AOAC (2012) metotlarına göre yapılmıştır.

\subsubsection{Kolesterol}

Tereyağı örneklerinde kolesterol miktarları AOAC (1996) metot no: 994.10 göre Shimadzu (GC-2010 model) gaz kromatografisi cihazı ile yapılmıştır. Cihaz; $60 \mathrm{~m}$ uzunluk, $0.25 \mathrm{~mm}$ iç çap ve $0.25 \mu \mathrm{m}$ film kalınlığına sahip TRB 5 MS model kolona sahiptir. Cihazın analitik şartları; enjeksiyon bloğu sıcaklığı: $280^{\circ} \mathrm{C}$, enjeksiyon modu: split, akış kontrol modu: $180 \mathrm{kPa}$ basınç, split oranı: 50 ve enjeksiyon hacmi $1 \mu \mathrm{L}$ 'dir. Kolesterol tanımlaması ve miktar belirleme işlemi \%99.9 saflıkta standard kolesterol ile gerçekleştirilmiştir. Yağlardaki kolesterol içeriği $\mu \mathrm{g}$ $\mathrm{g}^{-1}$ cinsinden ifade edilmiştir.

\subsubsection{Yă̆ asit komposizyonu}

Yağ asitleri analizi için gaz kromatografisi (Shimadzu, model GC-2025) kullanılmıştır. GC kolonu olarak, Restek RT-2560 kapiler kolon (100 m x $0.25 \mathrm{~mm}$ iç çap, $0.2 \mu \mathrm{m}$ film kalınlığı) ve FID (Alev İyonlaştırıcı Dedektör) dedektör kullanılmıştır. Cihazın çalışma parametreleri; enjeksiyon bloğu (SPL): $225^{\circ} \mathrm{C}$, split:1/10, akış modu: doğrusal hız, kolon sıcaklık programı: $100{ }^{\circ} \mathrm{C}-4 \mathrm{dk}$. Sıcaklık artışı: $3^{\circ} \mathrm{C} \mathrm{dk}^{-1}\left(240^{\circ} \mathrm{C}-20 \mathrm{dk}\right.$.), dedektör sıcaklığı: $250^{\circ} \mathrm{C}$, örnekleme hızı: $40 \mathrm{~ms}$ (AOAC, 2000) olarak ayarlanmıştır.

\subsubsection{Istatistiksel analizler}

SPSS $^{\circledR}$ paket programı (ver.23, IBM, ABD) kullanılarak yürütülen analizlerden elde edilen verilerin istatistiksel olarak değerlendirilmesi yapılmıştır. Verilerin değerlendirilmesinde tek yönlü varyans (ANOVA) analizi kullanılmış ve istatistiksel olarak önemli bulunan ortalamalar arasındaki farklılıklar, Duncan çoklu karşılaş̧ırma testi ile belirlenmiştir. Farklıların \%5 seviyesinde istatistiksel olarak önemli olduğu belirlenmiştir.

\section{Araştırma Sonuçları ve Tartışma}

Örneklerin su miktarları, yağ miktarları ve randımanları ile tereyağların istatiksel değerlendirmeleri Tablo l'de verilmiştir. Sütün su miktarı \%83.80 bulunmuş, yayık tereyağının (\%12.25) su oranının krema tereyağından (ekşi krema tereyağının: \%12.58, tatlı krema tereyağı: \%13.08) daha düşük olduğu belirlenmiş̧tir. Örneklerin su miktarları Türk Gıda Kodeksi (TGK, 2000) yönetmeliğine (en yüksek \%16) göre uygun bulunmuş̧tur. Tek yönlü varyans analizine göre kullanılan tereyağların su miktarları arasında fark istatistiksel olarak önemsiz bulunmuştur (p>0.05). Ergöz (2017), Haddar (2017), Ayar ve ark., (2006), Sagdıç ve ark., (2002) ve Hayaloğlu (1999) tereyağ üzerine yaptıkları çalışmalarında su miktarlarını bu çalışmadan daha yüksek bulurken, Tuğcu (2005)'nun sonuçları daha düşüktür. Altun ve ark., (2011) ile Şenel ve ark., (2010) çalışmaları arasında benzerlik bulunmuştur. 
Farklı Yöntemlerle Anadolu Manda Tereyağı Üretimi

Tablo 1. Örneklerin su miktarları, yă̆ miktarları ve randımanları

Table 1. Yields, fat and water contents of the samples

\begin{tabular}{llll}
\hline Örnek & $\mathrm{Su}(\%)$ & Yağ $(\%)$ & Randıman \\
\hline Manda sütü & 83.80 & 7.25 & - \\
Yayık tereyağ 1 & $12.25^{\mathrm{a}}$ & $83.25^{\mathrm{a}^{*}}$ & $8.50^{\mathrm{b}}$ \\
Tatlı krema tereyağı & $13.08^{\mathrm{a}}$ & $83.50^{\mathrm{a}}$ & $8.75^{\mathrm{b}}$ \\
Ekşi krema tereyağ & $12.58^{\mathrm{a}}$ & $84.16^{\mathrm{a}}$ & $7.00^{\mathrm{a}}$ \\
\hline *Aynı harfler ile gösterilen değerler arasında istatistiksel olarak fark yoktur (p>0.05)
\end{tabular}

Diğer çalışmalardaki bazı örnekler arasında da benzerlik olduğu gözlemlenmiştir (Gün, 2003; Urkun ve Oysun, 1998). Manda sütündeki yağ miktarı \%7.25 bulunmuștur. Yayık tereyağının yağ miktarı \%83.25, tatlı krema tereyağında $\% 83.50$ ve ekşi krema tereyağında $\% 84.16$ olduğu belirlenmiştir. Türk Gıda Kodeksine (TSE, 2015) göre tereyağların en az \%80 yağ içermesi gerektiği bildirilmiştir. Örnek tereyağların yağ miktarları TGK (2005)'ya göre uygun olduğu bulunmuştur. Yağ miktarları arasındaki fark önemsiz çıkmıştır (p>0.05). Yayık tereyağı (\%8.5) randımanı krema tereyağından (\%7-7.85) daha düşük olduğu belirlenmiştir. Manda sütünün yağ oranının yüksek olduğu bilinmektedir, siyah alaca sığırlarının sütleri (Önal ve ark., 2021) ile karşılaştırıldığında yaklaşık iki kat fazla olduğu görülmektedir. Bunlara ek olarak Şahin ve ark., (2014) iki gruba ayırdıkları toplam 149 baş Anadolu mandasının sütlerinin yağ düzeylerini ortalama \%5.76 olarak bulmuşlardır. Şenel ve ark., (2010), Şenel (2006) ve Efe (1998) tereyağı üzerine yaptıkları çalışmalarda yağ miktarlarını bu çalışmadan daha yüksek bulurken, Ergöz (2017), Haddar (2017), Tosun (2016), Akgül (2015), Gündoğdu (2012), Fındık (2011), Seçkin ve ark., (2005), Sağdıç ve ark., (2004), Bakırcı ve ark., (2004), Sağdıç ve ark. (2002) ve Aykanat (1995)'ın yaptıkları çalışmaların sonuçları ise daha düşüktür. Bu çalışmadaki sonuçların Bilgin (1996)'in yaptı̆̆ı çalışmayla benzer olduğu tespit edilmiştir. Yayık ve krema tereyağların randımanları arasında fark istatistiksel olarak önemli $(\mathrm{p}<0.05)$ bulunurken, tatlı ve ekşi krema tereyağı arasındaki fark istatistiksel olarak önemsiz ( $>0.05)$ bulunmuştur. Şenel (2006)'ın tereyağı üzerine yaptığı çalışmasında randıman oranı; mevcut çalışmadaki yayık tereyağı ve tatlı krema tereyağından düşük bulunurken, ekşi krema tereyağından yüksek bulunmuştur. Şekil l'de süt ve tereyağların $\mathrm{pH}$, titrasyon asitliği, serbest yağ asitliği ve peroksit değerleri ile istatiksel değerlendirmeler verilmiştir. Sütün $\mathrm{pH}$ değeri 6.54 olarak bulunurken yayık tereyağı $\mathrm{pH}$ değerinin (5.01) krema tereyağlarından (5.07-5.36) daha düşük olduğu görülmüş̧ür. Tereyağların $\mathrm{pH}$ değerleri arasında fark istatistiksel olarak önemsiz çıkmıştır ( $>0.05)$. Kahyaoğlu (2014), Gündoğdu (2012), Koyuncu (2010) ve Ayar ve ark., (2006) tereyağ üzerine yaptıkları çalışmalarda pH değerlerini bu çalışmadan daha yüksek bulurken, Akgül (2015), Şenel ve ark., (2011), Sağdıç ve ark., (2004) ve Sağdıç ve ark., (2002)'nın sonuçları ise daha düşüktür. Bu çalışmadaki sonuçların Şimsek (2011) ve Atamer ve ark., (2005)'in yaptıkları çalışmalarla benzer olduğu tespit edilmiştir.

Sütün titrasyon asitliği \%0.19, tereyağlarda ise \%0.18-0.41 aralığında olduğu belirlenmiştir. Tatlı ve ekşi krema tereyağları arasında fark bulunmazken yayık tereyağının titrasyon asitliği yüksek bulunmuştur $(\mathrm{p}<0.05)$. Ergöz (2017), Haddar (2017), Koyuncu (2010), Şengül ve ark., (1998) tereyağlar üzerine yaptıkları çalışmada titrasyon asitliklerini daha yüksek bulurken, Gündoğdu (2012), Şimsek (2011), Gürsel ve ark., (2006) ve Bakırcı ve ark., (2004)'nın sonuçları daha düşüktür. Çalışmadaki sonuçların Kahyaoğlu (2014), Sağdıç ve ark. (2004), Sağdıç ve ark., (2002) ve Hayaloğlu (1999)'nun yaptıkları çalışmalardaki titrasyon asitlikleriyle benzer olduğu tespit edilmiştir. Sütün peroksit sayısı $\left(0.10\right.$ meq $\left.\mathrm{O}_{2} \mathrm{~kg}^{-1}\right)$ düşük bulunmuştur. Yayık tereyağı peroksit değeri $(2.1 \mathrm{meq}$ $\left.\mathrm{O}_{2} \mathrm{~kg}^{-1}\right)$ krema tereyağlarından (1.75-1.94 meq $\left.\mathrm{O}_{2} \mathrm{~kg}^{-1}\right)$ daha yüksek bulunmuştur. Yayık tereyağ tereyağı ile tatlı krema tereyağı arasındaki farklılık istatistiksel olarak önemli bulunmuştur $(\mathrm{p}<0.05)$. Tosun (2016), Ayar ve ark., (2006) ve Hayaloğlu (1999)'nun tereyağı üzerine yaptıkları çalışmalardaki peroksit sayıları bu çalışmadan daha yüksek iken, Haddar (2017), Gündoğdu (2012) ve Atamer ve ark., (2005)'nın sonuçları ise daha düşüktür. Findık (2011), Şenel ve ark., (2011), Koyuncu (2010), Akarca (2010), Gürsel ve ark., (2006), Kaya (2000) ve Şengül ve ark., (1998)'nın yaptıkları çalışmalardaki peroksit sayılarıyla da benzerlik göstermiştir. Sütün serbest yağ asitliği $0.66 \mathrm{mg} \mathrm{KOH} \mathrm{g}{ }^{-1}$ yağ, tereyağlarda $0.84-2.11 \mathrm{mg} \mathrm{KOH} \mathrm{g}^{-1}$ yağ arasındadır. Üç tereyağın serbest yağ asitlikleri arasında fark istatistiksel olarak önemli bulunmuştur ( $<<0.05)$. Uruk (2011), Ayar ve ark., (2006), Bakırcı ve ark., (2004), Atamer ve ark., (2004) ve Hayaloğlu (1999) tereyağı üzerine yaptıkları çalışmalardaki asit sayılarını mevcut çalışmadan daha yüksek bulurken, Şimsek (2011), Öztekin-Öztürk (2010), Sağdıç ve ark., (2004) ve Sağdıç ve ark., (2002)'nın sonuçları ise daha düşüktür. Ergöz (2017), Kahyaoğlu (2014), 
Gündoğdu (2012), Şenel (2006), Gürsel ve ark., (2006) ve Atamer ve ark., (2005)'nın yaptıkları çalışmalardaki asit sayılarıyla da benzer olduğu belirlenmiştir.

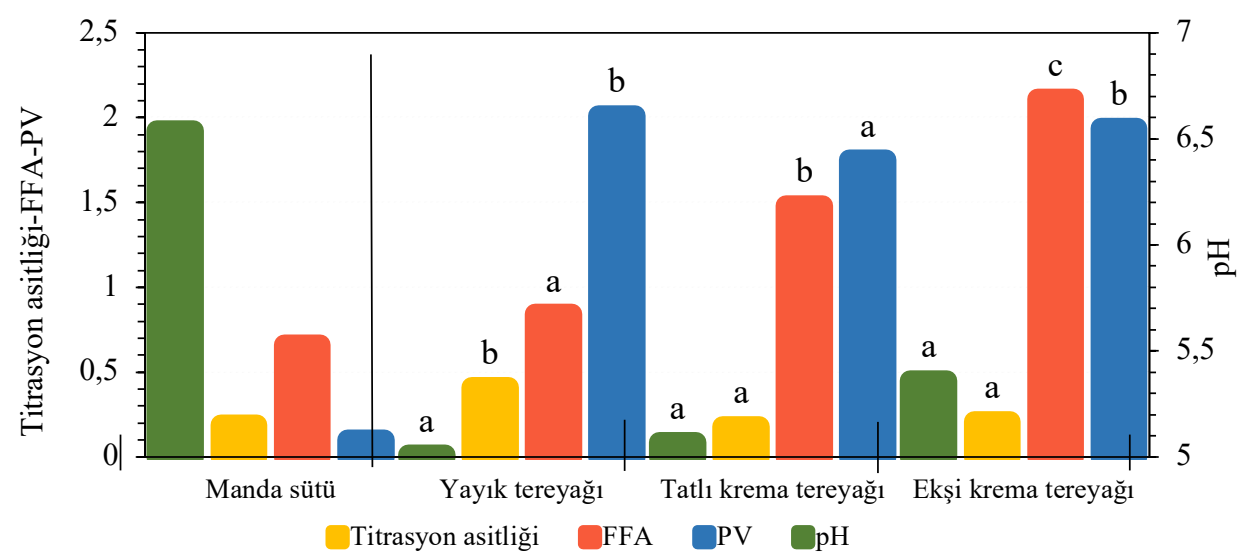

Aynı harfler ile gösterilen değerler arasında istatistiksel olarak fark yoktur ( $p>0.05)$

Figure 1. Ph, titrable asit, free fatty acid (FFA) and peroxide (PV) values of the samples

Şekil 1. Örneklerin pH, titrasyon asitliği, serbest yă̆ asitliği (FFA) ve peroksit (PV) değerleri

Süt, yayık tereyağı tatlı krema tereyağı ve ekşi krema tereyağının vitamin içerikleri ile yağlar arasındaki istatiksel değerlendirmeler Şekil 2'de verilmiştir. Yağların Vitamin A içerikleri birbirinden farklılık göstermiştir, en yüksek Vitamin A içeriği tatlı krema tereyağında tespit edilmiştir ( $\mathrm{p}<0.05)$. Urkun (1997), tereyağı üzerine yaptığı çalışmadaki A vitamini miktarları bu çalışmadan daha yüksek bulurken, Kahyaoğlu (2014), Mallia ve ark. (2008b), Hulshof ve ark. (2006), Fatouh ve ark., (2005) ve Hewavitharana ve ark., (1996)'nın sonuçları ise daha düşüktür.

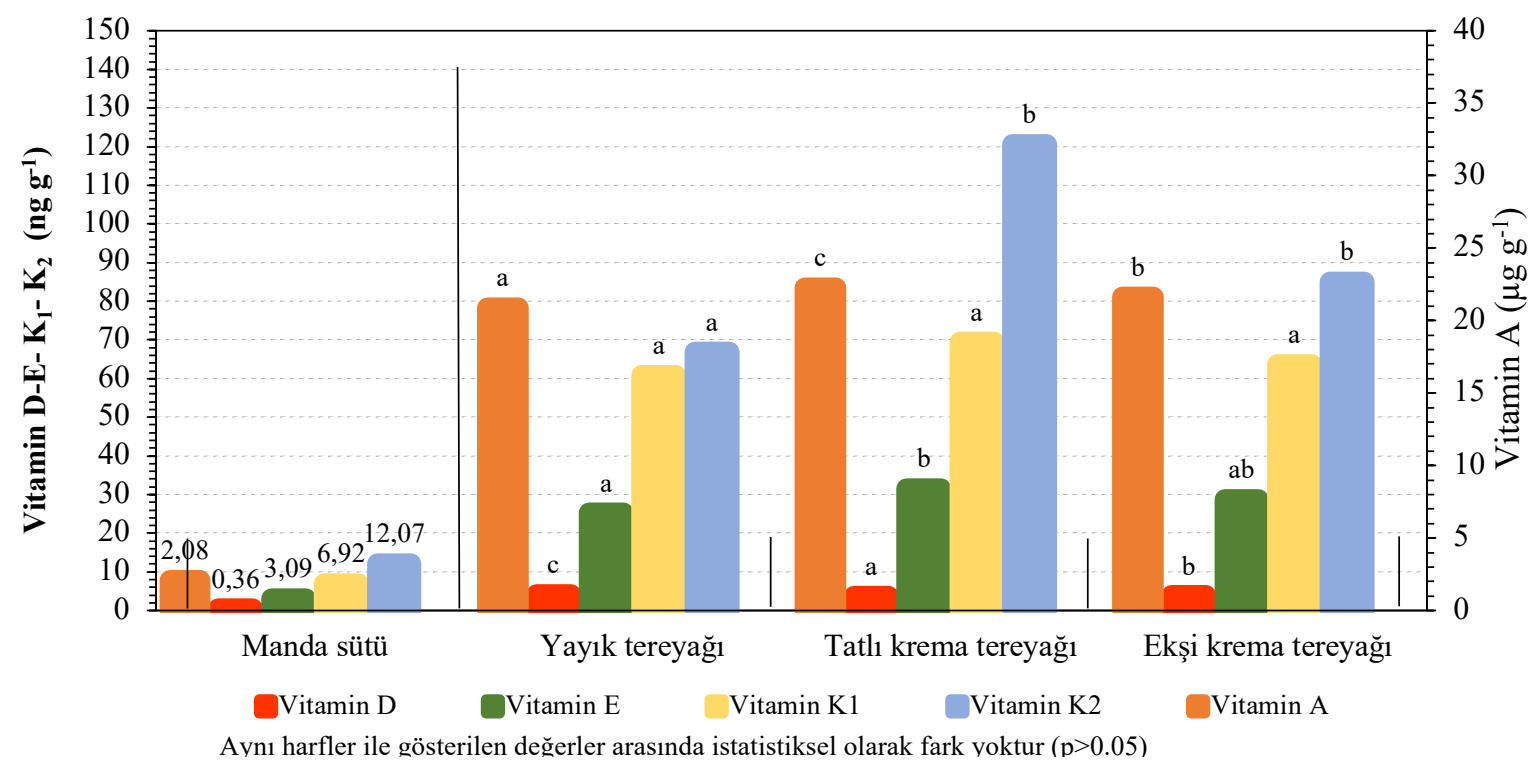

Figure 2. Vitamin contents of the samples

Şekil 2. Örneklerin vitamin içerikleri

Tereyağ örneklerinin D vitamini içerikleri 3.58-4.175 $\mathrm{ng} \mathrm{g}^{-1}$ arasında değiştiği ve istatiksel olarak fark olduğu belirlenmiştir ( $\mathrm{p}<0.05)$. Fatouh (2005)'un Tereyağ üzerine yaptığı çalışmadaki D vitamini miktarı bu çalışmadan daha yüksektir. Ekşi krema tereyağı örneğinin Vitamin E içeriği diğer örneklere yakın bulunmuştur, fakat yayık ve tatlı krema tereyağı örnekleri arasında önemli fark belirlenmiştir $(p<0.05)$. Önceki iki çalışmadaki $E$ vitamini miktarları bu çalışmadan daha düşüktür (Fatouh, 2005, Hewavitharana ve ark., 1996). Sütün $K_{1}$ ve $K_{2}$ vitamin içerikleri sırasıyla 6.92 ve $12.07 \mathrm{ng} \mathrm{g}^{-1}$ olarak bulunmuştur. Tereyağlarında bu değerler $\mathrm{K}_{1}$ için $60.8-69.4 \mathrm{ng} \mathrm{g}^{-1}$, $\mathrm{K}_{2}$ için 66.8-120.6 ng g-1 arasında değiştiği belirlenmiştir. Yağ örneklerinin $\mathrm{K}_{1}$ içerikleri arasında fark bulunmazken ( $\mathrm{p}>0.05), \mathrm{K}_{2}$ içeriklerinin birbirlerinden farklı olduğu tespit edilmiştir $(\mathrm{p}<0.05)$. 
Süt ve yağ örneklerinin kolesterol seviyeleri Şekil 3'de yağlar arasındaki istatiksel değerlendirme ile birlikte verilmiştir. Kolesterol içerikleri sütte $69 \mu \mathrm{g} \mathrm{g}^{-1}$, yayık tereyağında $2854 \mu \mathrm{g} \mathrm{g}^{-1}$, tatlı krema tereyağında $2256 \mu \mathrm{g} \mathrm{g}$ ${ }^{1}$ ve ekşi krema tereyağında $1554 \mu \mathrm{g} \mathrm{g}^{-1}$ bulunmuş, yağ örnekleri arasında önemli farklar olduğu belirlenmiştir $(p<0.05)$. Fatouh (2005), Seçkin ve ark., (2005), Urkun (1997), ve Şenel (1991)'in sonuçları bu çalışmadan daha yüksek iken, Fındık (2011) ve AI-Khalifa ve AI-Kahtani (1993)'ın sonuçlarının ise benzer olduğu görülmüştür.

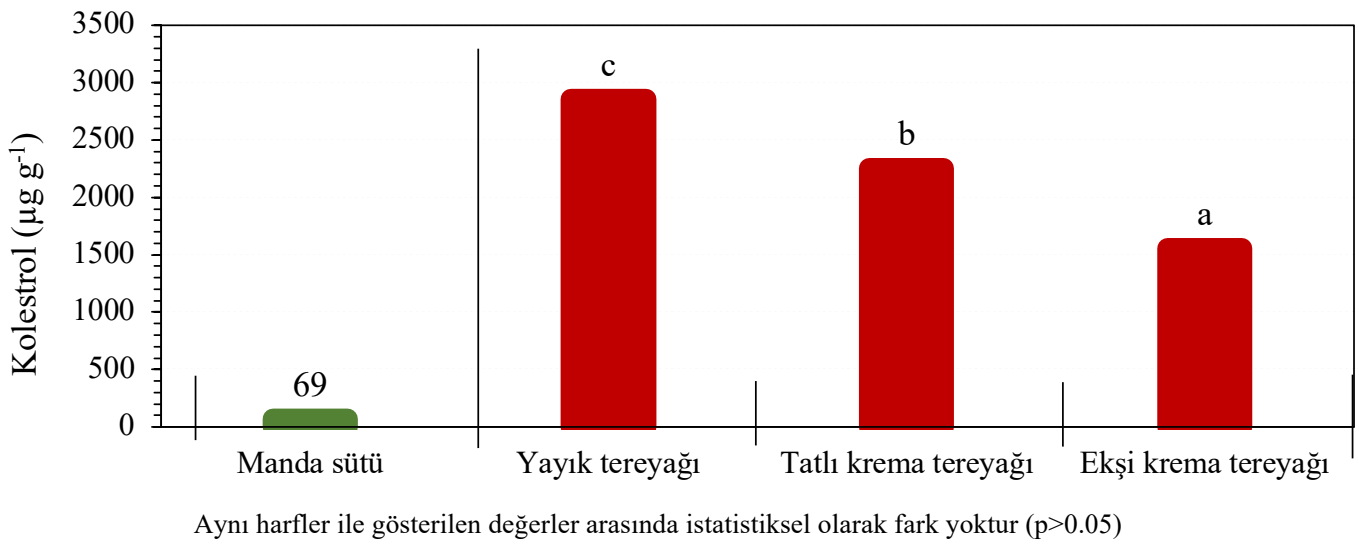

Figure 3. Cholesterol amounts of the samples

Şekil 3. Örneklerin kolesterol miktarlart

Süt ve tereyağı örneklerinin yağ asit kompozisyonları analizinde 24 tane aynı yağ asiti tespit edilmiştir. Örneklerdeki yağ asitleri istatiksel olarak değerlendirildiğinde aralarında fark olmadığı belirlenmiştir $(\mathrm{p}<0.05)$. Bu yüzden Tablo 2'de her bir yağ asidinin ortalama değerleri gösterilmiştir.

Tablo 2. Manda sütünün ve tereyă̆larının ortalama yă̆ asit kompozisyonu (\%)

Table 2. Mean fatty acid composition of buffalo milk and the butters (\%)

\begin{tabular}{ll}
\hline Yağ asiti & $\begin{array}{l}\text { Ortalama } \\
\text { değer (\%) }\end{array}$ \\
\hline Bütirik Asit $\left(\mathrm{C}_{4: 0}\right)$ & 3.80 \\
Kaproik Asit $\left(\mathrm{C}_{6: 0}\right)$ & 1.25 \\
Kaprilik Asit $\left(\mathrm{C}_{8: 0)}\right)$ & 0.73 \\
Kaprik Asit $\left(\mathrm{C}_{10: 0}\right)$ & 1.36 \\
Laurik Asit $\left(\mathrm{C}_{12: 0}\right)$ & 1.75 \\
Miristik Asit $\left(\mathrm{C}_{14: 0)}\right)$ & 8.98 \\
Miristoleik Asit $\left(\mathrm{C}_{14: 1}\right)$ & 1.87 \\
Pentadekanoik Asit $\left(\mathrm{C}_{15: 0}\right)$ & 1.97 \\
Cis-10-pentadecanoik Asit $\left(\mathrm{C}_{15: 1)}\right)$ & 0.86 \\
Palmitik Asit $\left(\mathrm{C}_{16: 0}\right)$ & 36.07 \\
Palmiteloik Asit $\left(\mathrm{C}_{16: 1)}\right)$ & 3.26 \\
Heptadekanoik Asit $\left(\mathrm{C}_{17: 0)}\right)$ & 1.18 \\
Cis-10-Heptadekanoik Asit $\left(\mathrm{C}_{17: 1}\right)$ & 0.47 \\
Stearik Asit $\left(\mathrm{C}_{18: 0}\right)$ & 9.30 \\
Oleik Asit $\left(\mathrm{C}_{18: 1)}\right)$ & 24.19 \\
Linoleik Asit $\left(\mathrm{C}_{18: 2}\right)$ & 1.06 \\
Alfa-Linolenik Asit $\left(\mathrm{C}_{18: 3}\right)$ & 0.34 \\
Arasidik Asit $\left(\mathrm{C}_{18: 0}\right)$ & 0.18 \\
Cis-11-Eicosenoik Asit $\left(\mathrm{C}_{20: 4}\right)$ & 0.60 \\
Heneicosanic Asit $\left(\mathrm{C}_{21: 0}\right)$ & 0.13 \\
Behenic Asit $\left(\mathrm{C}_{22: 0}\right)$ & 0.25 \\
Erucic Asit $\left(\mathrm{C}_{22: 1)}\right.$ & 0.16 \\
Tricosenoik Asit $\left(\mathrm{C}_{23: 1)}\right)$ & 0.18 \\
Lignoceric Asit $\left(\mathrm{C}_{24: 0}\right)$ & 0.15 \\
\hline
\end{tabular}

Örneklerde \% olarak en yüksek serbest yağ asidi palmitik asit iken, en düşük ise heneicosanic asit olarak belirlenmiştir. Atasoy ve Türkoğlu (2010), Atamer ve ark. (2005), Seçkin ve ark., (2005), Şengül ve ark., (2003) 
ve Egan (1981)'nın tereyağı üzerine yaptıkları çalışmalardaki bütirik asit miktarları bu çalışmadan daha düşük bulunmuştur. Şengül ve ark. (2003) kaproik asit miktarını bu çalışmadan daha yüksek bulurken, Atamer ve ark. (2005)'nın sonuçları ise daha düşüktür. Şengül ve ark., (2003) kaprilik asit miktarını bu çalışmadan daha yüksek bulurken, Atamer ve ark. (2005)'nın çalışmalarındaki kaprilik asit miktarları ise daha düşüktür. Şengül ve ark., (2003) kaprik asit miktarını bu çalışmadan daha yüksek, Atamer ve ark. (2005) ise daha düşük bulmuşlardır. Laurik asit ve miristik asit miktarlarında da bu araştırmacılarla benzer durum gözlemlenmiştir. Palmitik asit ve stearik asit miktarlarında Atasoy ve Türkoğlu (2010) ile benzerlik olduğu tespit edilmiştir. Fakat Atasoy ve Türkoğlu (2010), Seçkin ve ark., (2005) ve Egan (1981) buldukları oleik asit değerleri daha yüksek olduğu belirlenmiştir.

\section{Sonuç}

Yoğurt, tatlı krema ve ekşi kremalardan üretilen manda tereyağların bazı kalite parametreleri incelenmiş̧ir. Üretim tekniklerinin tereyağların su ve yağ içerikleri üzerinde etkisi gözlenmezken randıman üzerinde etkisi olduğu belirlenmiş̧ir. Ekşi kremanın randımanı diğer örneklere göre daha düşük çıkmıştır. Tereyağların $\mathrm{pH}$ değerleri arasında fark bulunmazken, titrasyon asitliği, serbest yağ asitliği ve peroksit değerlerinde farklılıklar belirlenmiş̧tir. Yayık tereyağın titrasyon asitliği ile peroksit değerinin yüksek olmasına karşın serbest yağ asitliği değerinin önemli derecede düşük olduğu görülmüştür. $\mathrm{K}_{1}$ vitamini hariç diğer vitamin değerleri arasında farklılıklar bulunmaktadır. Yağ asiti kompozisyonlarına bakıldığında süt dahil örnekler arasında önemli değişiklik bulunmamıştır. Üç yöntemle üretilen tereyağların bazı parametrelerinde benzerlik bazı parametrelerde ise farklılık tespit edilmesine karşın ekşi kremadan yapılan tereyağının kolesterol içeriğinin diğer yöntemlerle üretilen tereyağlara kıyasla düşük bulunması bu üretim tekniğini öne çıkarmaktadır.

\section{Teşekkür}

$\mathrm{Bu}$ çalışma KSÜ Bilimsel Araştırma Projeleri Birimi tarafindan 2015/1-18YLS proje numarası ile desteklenmiştir. 


\section{Kaynakça}

Akarca, G. (2010). Afyonkarahisar İlinde Tüketime Sunulan Karınyağlarının (Tereyă̆ı) Gıda Güvenliği Açısından İncelenmesi. (Yüksek Lisans Tezi) Afyonkarahisar.

Akgül, H.ì. (2015). Trabzon Tereyağlarının Bazı Kalite Parametrelerinin Belirlenmesi. (Yüksek Lisans Tezi) Erzurum.

Al-Khalifa, A., Al-Kahtani H. (1993). Composition of ghee (Samn Barri's) from cow's and sheep's milk. Food Chemistry, 46: 373-375.

Altun, İ., Andıç, S., Tunçtürk, Y., Çeçen, A., Fındık, O. (2011). Van piyasasından temin edilen tereyağlarının bazı kimyasal özellikleri. Kafkas Üniversitesi Veteriner Fakültesi Dergisi, 17(4): 645-648.

AOAC. (1996). Official Methods of Analysis of AOAC International, $16^{\text {th }}$ edn., Association of Official Analytical Chemists, Washington, DC.

AOAC. (2000). Fatty acids in oils and fats-Official Method 969.33 17th ed., AOAC International Arlington-Virginia USA.

AOAC. (2012). The Official Methods of Analysis of AOAC International (American Official Analytical Chemists), $19^{\text {th }}$ Edition by Jr. Dr. George Latimer, Gaithersburg, Maryland.

AOCS. (2000b). Fat content of raw and pasteurized whole milk. Gerber method by weight, Official Method 2000.18, Gaithersburg, MD, USA.

AOCS. (2006). Official methods of analysis Lipids, Fats and Oils Analysis Peroxide Value Fats and Oils -Method 965.33; Urbana, USA.

AOCS. (2009). Official methods of analysis Lipids, Fats and Oils Analysis Free Fatty Acids-Method Ca 5a-40; Urbana, USA

Atamer, M., Şenel, E. and Öztekin, Ş. (2004). A Traditional Product: Yayık Tereyağ Conventional Way of Manufacturing and Its Some Properties. International Dairy Symposium. Recent Developments in Dairy Science and Technology, 149-152, Isparta.

Atamer, M., Şenel, E. ve Öztekin, Ş. (2005). Yoğurttan Üretilen Tereyağlarının (Yayık Tereyağı) Bazı Niteliklerinin Belirlenmesi. TÜBiTAA, TOGTAG-3035 No'lu proje, 37, Ankara

Atasoy, F., Türkoğlu, H. (2010). Şanlıurfa'da üretilen ve satışa sunulan sadeyağların (Urfa yağı) serbest yağ asitleri bileşiminin belirlenmesi üzerine bir araştırma. Harran Üniveristesi Ziraat Fakültesi Dergisi, 14(2): 9-12.

Ayar, A., Özcan, M., Sert, D., Arslan, D. (2006). Yayık tereyağının raf ömrünün uzatılmasına bazı baharat, uçucu yağ ve ekstraktlarının katkısı. TÜBİTAK, TOVAG-105 O 046 No'lu proje, Konya

Aykanat, Z. (1995). Adana ilinde Tüketime Sunulan Bazı Süt Ürünlerinin Fiziksel ve Kimyasal Özellikleri Açısından Standartlara Uygunluğunun Araşttrlması. (Yüksek Lisans Tezi) Adana

Bakırcı, I., Çelik S, Coskun H. (2004). Mezofilik liyofilize starter kültür kullanarak üretilen tereyağının bazı özellikleri. Gıda, 29(1): 57-62.

Bilgin, B. (1996). Tatlı ve dört farklı kültür kombinasyonu ile ekşitilen kremalardan elde edilen tereyağlarının depolama süresince, bazı duyusal, fiziksel, kimyasal ve mikrobiyolojik özelliklerinin belirlenmesi üzerine bir arastırma. (Doktora tezi) Trakya Üniversitesi Fen Bilimleri Enstitüsü. Tekirdağ.

Demiryürek, K. (2004). Dünya ve Türkiye’de organik tarım. Harran Üniversitesi Ziraat Fakültesi Dergisi, 8(3-4): 63-71.

Efe, M. (1998). Ankara Piyasasında Tüketime Sunulan Vakum Paketli Kahvalttllk Tereyağların Gıda Maddeleri Tüzüğ̈̈, T.S.E ve MSB Kahvalttllk Tereyağı Şartnamesine Uygunluğunun Saptanması. (Yüksek Lisans Tezi) Ankara Üniversitesi.

Egan, H., Kirk, R.S., Sawyer, R. (1981). Oils and Fats, Chapter. 17. Pearson's Chemical Analysis of Foods (Editor: H. Egan). Churchill Livingstone: Edinburg. p. 534-539.

Ergöz, E. (2017). Manda Sütünden Üretilen Yaylk ve Krema Tereyağlarının Nitelikleri. (Yüksek Lisans Tezi) Ankara.

FAO. (2021a). http://www.fao.org/faostat/en/\#data/QA, (Erişim tarihi 14.08.2021)

FAO. (2021b). http://www.fao.org/faostat/en/\#data/QA, (Erişim tarihi 18.08.2021)

Fatouh, A.E, Singh, R.K, Koehler, P.E., Mahran, G.A., Metwally, A.E. (2005). Physical, chemical and stability properties of buffalo butter oil fractions obtained by multi-step dry fractionation. Food Chemistry, 89: 243-252.

Findık, O. (2011). Van'da Piyasaya Sunulan Bazı Tereyağları ile Bu Tereyağlardan Elde Edilen Sadeyağların Bazı Kimyasal Ve Mikrobiyolojik Özelliklerinin Karşılaştırlması. (Yüksek Lisans Tezi) Van.

Gün, İ. (2003). Burdur’da Üretilen Karınyağlarının Bazı Kalite Özellikleri ve Üretim Teknolojisi, Süleyman Demirel Üniversitesi Fen Bilimleri Enstitüsü Dergisi, 7(3): 55-59.

Gündoğdu, E. (2012). Yoğurt ve Kremadan Üretilen Tereyağlarının Aroma Profili ve Bazı Kalite Özellikleri Üzerine Kültür Kullanımının ve Muhafaza Süresinin Etkileri. (Doktora Tezi) Atatürk Üniversitesi Fen Bilimleri Enstitüsü. Erzurum

Gürsel, A., Pamuk, Ü., Şenel, E., Şanlı, E. (2006). Kremanın dondurularak muhafazası üzerine bir araştırma. Gıda, 31: 151-157 
Haddar, M. (2017). Yayık Tereyağı Üretiminde Farklı Kültür Kullanım Olanaklarının Araştırılması. (Yüksek Lisans Tezi) Ankara

Hayaloğlu, A. (1999). Malatya Yöresinde Kremadan ve Yoğuttan Elde Edilen Çeșitli Tereyağlarının fizikokimyasal, Mikrobiyolojik ve Duyusal Nitelikleri Üzerine Karşılaştırmalı Bir Araştırma. (Yüksek Lisans Tezi) Çukurova Üniversitesi Fen Bilimleri Enstitüsü. Adana.

Hewavitharana, A.K., Van Brakel, A.S., Harnett, M. (1996). Simultaneous liquid chromatographic determination of vitamins A, E and $\beta$-carotene in common dairy foods. International Dairy Journal, 6: 613-624.

Hulshof, P.J.M., Roekel-Jansen T., Bovenkampy P., Westz C. (2006). Variation in retinol and carotenoid content of milk and milk products in The Netherlands. Journal of Food Composition and Analysis, 19: 67-75.

Kahyaoğlu, D.T. (2014). İnek, Koyun ve Keçi Sütlerinden Üretilen Tereyağlarında Depolama Süresince Uçucu Bileşikler, Oksidasyon Stabilitesi ve Diğer Bazı Kalite Kriterlerinin Belirlenmesi. (Doktora Tezi) Erzurum.

Kaya, A. (2000). Properties and stability of butter oil obtained from milk and yoghurt. Nahrung, 44: 126-129.

Koyuncu, M. (2010). Farklı Muhafaza Şartlarında Tereyağının Bazı Niteliklerinde Meydana Gelen Değişiklikler. (Yüksek Lisans Tezi) Van.

Mallia, S., Escher, F., Schlichtherle-Cerny, H. (2008a). Aroma-active compounds of butter: A Review. European Food Research and Technology, 226: 315-325.

Mallia, S., Piccinali, P., Rehberger, B., Badertscher, R., Escher, F. and Schlichtherle-Cerny, H. (2008b). Determination of storage stability of butter enriched with unsaturated fatty acids/conjugated linoleic acids (UFA/CLA) using instrumental and sensory methods, International Dairy Journal, 18(10-11): 983-993.

Metin, M. (2008). Süt Teknolojisi-Sütün Bileşimi ve İşlenmesi (Yedinci Baskı). Ege Üniversitesi Mühendislik Fakültesi Yayın No: 33 , 802 s. Bornova, İzmir.

Önal, A.R., Özkan, M., Tuna Y.T., (2021). Siyah Alaca Süt Sığırlarında Mevsim ve Laktasyon Sırasının Sütün Bileşimi ve Kalitesine Etkisi. Tekirdă̆ Ziraat Fakültesi Dergisi, 18(2): 368-374.

Öztekin Öztürk, F.Ş. (2010). Yoğurdun Sulandırma Oranı ve Granüllerin Yıkama Sayısının Yayık Tereyağının Nitelikleri Üzerine Etkisi. (Doktora tezi) Ankara Üniversitesi Fen Bilimleri Enstitüsü. Ankara.

Sağdic, O., Arici, M., Simsek, O. (2002). Selection of starters for a traditional Turkish Yayik butter made from yoghurt. Food Microbiology, 19: 303312 .

Sağdic, O., Donmez, M., Demirci, M. (2004). Comparison of characteristic and fatty acid profiles of Traditional Turkish Yayik butters produced from goats', ewes' or cows' milk. Food Control, 15: 485-490.

Seçkin, A.K., Gürsoy, O., Kınık, Ö., Akbulut, N. (2005). Conjugated linoleic acid (CLA) concentration, fatty acid composition and cholesterol content of some Turkish dairy products. LWT-Food Science and Tecnology, 38: 909-915.

Şahin, A. Yıldırım A, Ulutaş, Z., (2014). Anadolu Mandalarında Bazı Çiğ Süt Parametreleri ile Somatik Hücre Sayısı Arasındaki İlişkiler. Tekirdăg Ziraat Fakültesi Dergisi, 11(1): 114-121.

Şenel, E. (2006). Bazı Üretim Parametrelerinin Yoğurttan Üretilen Yayık Tereyağının Nitelikleri Üzerine Etkisi. (Doktora Tezi) Ankara Üniversitesi Fen Bilimleri Enstitüsü Süt Teknolojisi Anabilim Dalı. Ankara.

Şenel, E., Atamer, M., Öztekin, F. Ş. (2011). The oxidative and lipolytic stability of yayık butter produced from different species of mammals milk (cow, sheep, goat) yoghurt. Food Chemistry, 127: 333-339.

Şenel, E., Atamer, M., Öztekin, Ş. (2010). Yayıklama parametrelerinin yayık ayranı ve yayık tereyağının bazı nitelikleri üzerine etkisi. Gıda, 35: 267274.

Şenel, S. (1991). Tereyağlarında kolesterol miktarlarının ve margarin varlı̆̆ının yüksek performanslı sıvı kromatografisi ile saptanması (Doktora Tezi, basılmamış) Atatürk Üniversitesi Sağlık Bilimleri Enstitüsü. Ankara

Şengül, M., Çakmakçı, S., Ünsal, M. (1998). Trabzon tereyağlarının bazı fiziksel ve kimyasal özelliklerinin tespiti. V. Süt ve Süt Ürünleri Sempozyumu, Geleneksel Süt Ürünleri (21-22 Mayıs 1998, Tekirdağ). Milli Prodüktivite Merkezi Yayınları No: 621, sayfa; 230-243, Tekirdağ

Şengül, M., Ünsal, M., Çakmakçı, S. (2003). Trabzon tereyağlarının yağ asidi kompozisyonunun tespiti. Süt Endüstrisinde Yeni Eğilimler Sempozyumu. 22-23 Mayıs, 2003, Bornova, İzmir. 363-365 s.

Şimsek, B. (2011). Studies on the storage stability of yayık butter. Journal für Verbraucherschutz und Lebensmittelsicherheit, 6: 175-181.

TGK. (2000). Türk Gıda Kodeksi Yönetmeliği Çiğ Süt ve Isıl İşlem Görmüş İçme Sütleri Tebliği Resmi Gazete: 14.02.2000-23964.

TGK. (2005). Türk Gıda Kodeksi, Tereyağı, Diğer Süt Yağı Esaslı Sürülebilir Ürünler ve Sadeyağ Tebliği (Tebliğ No: 2005/19). Gıda, Tarım ve Hayvancılık Bakanlığı, Ankara. 

Tosun, F. (2016). Ekzopolisakkarit Üreten Laktik Kültürlerin Tereyă̆ı, Yayık Tereyağı ve Kaymağın Kalite Özelliklerine Etkisi. (Doktora Tezi) Kayseri.

TSE (1995). TS 1331 Tereyağı Standardı. Türk Standartları Enstitüsü, Ankara.

TSE. (2015). Tereyağı TS 1331/T1, Türk Standardları Enstitüsü, Ankara

Tuğcu, M. (2005). Tereyağı Kalitesi Üzerine Farklı Kültür Kullanımının Etkileri. (Yüksek Lisans Tezi) Ege Üniversitesi. İzmir.

TÜIK. (2021a). http://www.tuik.gov.tr/PreTabloArama.do, (Erişim tarihi: 14.08.2021)

TÜIK. (2021b). http://www.tuik.gov.tr/PreTabloArama.do, (Erişim tarihi: 18.08.2021)

Urkun, T. (1997). Kolesterolü azalttlmış tereyağı üretimi ve bazı özelliklerinin araşstırlması. (Yüksek Lisans Tezi) Ege Üniversitesi. İzmir

Urkun, T., Oysun, G. (1998). Kolesterolü azaltılmış tereyağı ve bazı parametrelerinin belirlenmesi, Gıda Mühendisliği Kongre ve Sergisi, 16-18 Eylül, Gaziantep.

Uruk, H.A. (2011). Farklı Hayvan Sütlerinden Üretilen Tereyağlarının Lipit Kısmında Bazı Bileşen Farklllklarının Belirlenmesi. (Yüksek Lisans Tezi) Malatya

Üçüncü, M. (2005). Süt ve Mamülleri Teknolojisi. SiDAS, İzmir.

Zicarelli, L. (2004). Buffalo milk: its properties, dairy yield and Mozzarella production. Veterinary Research Communications, 28: 127-135. 